\title{
The past is another truth
}

Rosemary Auchmuty

ANUHJ Editor, 1970

The discipline of history was undergoing a revolution when I began my undergraduate studies at The Australian National University (ANU) in the late 1960s. Of course I did not realise it then, nor did I appreciate how different ANU was from more traditional history departments, though I think that some of our teachers were aware they were in the vanguard of change. My father was an old-style historian and for him, as for most historians, history was the story of public events and public figurespolitics, war and great men. Social history was in its infancy, and women's history did not exist. But at ANU we studied the civil rights movement in American history, which my father thought was not history at all, but current affairs. We studied Pacific history, which my father thought was anthropology. And in my honours year, I took 'Literature and History' for my special subject, and wrote a long essay on the work of Virginia Woolf, Elizabeth Bowen and Rosamond Lehmann. The women's movement had started, and I never did 'straight' history again—always social, always feminist. A door had opened and ANU swept me through it.

I chose to do a history degree because, like so many people, I had had an inspirational teacher at school. I had no idea about a future career (except that I did not want to teach), so I simply opted for what I loved. I realise now that this was naïve, in that there is very little one can do with a history degree except teach (or, in Canberra, join the public service, which in fact I did for the three months between graduating with an undergraduate degree and starting my $\mathrm{PhD}$ ). But I also see that I was victim of the general lack of career guidance at the time for young women (who were, after all, only going to marry-or teach). My father tried to stop me from going to ANU; he had once reviewed a book by Manning Clark rather critically and Manning fell out with him, and my father was worried that he would also take against me. This did not happen. Manning never taught me, but I evidently got on good terms with him in my undergraduate years as he chose to supervise my $\mathrm{PhD}$, even though it had nothing to do with Australian history. 
My long-term memory has always been terrible, moulded by selective suppression of unhappy or discordant experiences. (My short-term memory is excellent, so I did well at exams.) My overwhelming recollection of my years at ANU is one of misery and loneliness as a coastal fish (I came from Newcastle) quite literally out of water (you could not even swim in Lake Burley Griffin). In Newcastle, I had a close circle of schoolfriends and a secure place in the middle class of a largely working-class city. In Canberra, every other student seemed to be the offspring of a diplomat or politician. They were all privately educated and frighteningly articulate. Beside them, I felt like I knew nothing, that I was nothing.

Years later, as a university teacher myself, I came to realise that most young people feel unsure of themselves when they first leave home for higher education. What I had not realised, though, until last year when the editors approached me with evidence of my involvement with the ANU Historical Society and the ANUHJ, was that actually I was not always miserable and alone. I did not spend all my waking hours in the library preparing for classes (a solitary exercise in those days), sitting alone at meals in Bruce Hall, or wandering round the shopping mall by myself on Friday nights. I remember doing all those things, but at the same time, I seem to have been involved in the community of the History Department, putting myself forward for posts, bossily presiding over meetings and helping to edit a journal. I can now put faces to the names on the editorial committee and recall happy experiences: cycling round the lake with Caroline Turner and witty conversations (his wit, not mine) with Dennis Shoesmith. I wish I had remembered these experiences and achievements long ago. I would have felt differently about my student years. I did enjoy my studies; and now I see I enjoyed the extracurricular activities too. Pity it is too late to put the editorship on my CV.

The ANUHJ was basically a student journal. The number 6 issue (published in 1969 when I was in my second year) was fronted by an article by Bill Mandle, then a senior lecturer, also the historian who taught the Literature and History option I took in my final year. The second contribution was by a visiting professor from the US. But the other five articles were by students, including a first-year undergraduate. I do not think it occurred to me at the time that my contemporaries-people like Iain McCalman, Ian Britain and Susan Eade (née Magarey), a pioneer of women's studies in Australia-were going to become the scholars and professors of the future. 
The following year, 1970, I coedited the Journal with Helen McCallum. This time the leading article was by Helen's future PhD supervisor, FB ('Barry') Smith, then Senior Fellow in the Research School of Social Sciences in the Institute of Advanced Studies. It was followed by a piece by the visiting professor from Canada and three articles by students, including one by Caroline Turner, my friend from Bruce Hall. One of the book reviews was by John Thompson, another friend, who went on to have a long career at the National Library of Australia.

Two things strike me as I turn the pages of these beautifully produced journals. First, the range of contributors is impressive. To be able to include work by students at every level alongside that of senior academics is testimony to the quality of the students and teaching. I do not see this range in journals today. Second, the content of the contributions is revealing of the ANU History Department's interests and approaches to history. Mandle writes on 'Auden and the Failure of the Left' and honours graduate KS Oldmeadow on 'Petrarch and Leavis: A Perspective on Literature and History'. Other articles focused on race issues in the US and Australia, on British social history and on Russian populism. There was comparative work, twentieth-century history and historiography. These were state-of-the-art topics. There was no straight political history, nothing on war.

After I finished my $\mathrm{PhD}$, I took a lecturing post in Wollongong in an Institute of Higher Education, now part of the university, that had formerly been a teacher's college. There I learned to teach, and discovered - surprise, surprise- that this was in fact what I was good at. With colleagues at the university, we ran what must have been one of the first women's studies courses in the country. When my contract was not renewed after three years, I went to London. There I taught various history and women's studies classes in the then burgeoning adult education sector, and later for the Open University. The women's movement was in full swing and it was easier to put together a portfolio of part-time teaching than to try to get a full-time post in history with all the British competition. Or perhaps I just did not try, because I was enjoying myself so much being a feminist. All my life I have had to be encouraged to step up to challenges or, more prosaically, to take my career seriously. I do not think this was just a personal failing; I think I was a woman of my time and class, seduced by the ease of getting work of some sort in the 1970s and 1980s (so unlike the instrumental approach of students of today), but held back by the low expectations of women, discouragement and active opposition to aiming for serious jobs. 
I moved into law following a stint on jury service and a yearning for further intellectual challenge. The polytechnic where I did my part-time LLB offered me a job when I completed my degree; law was at a much less advanced stage of development in higher education at the time and I was the only person in my department with a $\mathrm{PhD}$. Now, after 30 years in law schools, I have come back to history as my primary research discipline. With a colleague from Birmingham, Erika Rackley, I have coordinated a project called Women's Legal Landmarks to celebrate the centenary of women's admission into the legal profession in the UK and Ireland. A hundred participants have 'landmarked' important events in women's legal history, so often ignored or misrepresented, to set down an accurate record for the scholars and citizens of tomorrow.

Last year I returned to ANU for the first time in decades. The campus was much changed: there were three times as many buildings; Bruce Hall had been razed to the ground. Seeing the places where I had spent six such formative years of my life forced me to confront my past. It was a moving experience. So was looking at these journals: here it is in print and I cannot deny it.

Part of the appeal of history lies in its capacity to move us: these were real people; these things really happened. We see patterns of behaviour in the past; we find chains of cause and effect, but they are never entirely predictable. So, subjecting my past to the historian's critical scrutiny, can I see how my days as a student historian moulded my future life? Well, they made me a good historian, if I say so myself. From the start of my academic career, I espoused a radical view of the ends and methodologies of history precisely because these were what I was exposed to as an undergraduate. And they helped to make me a teacher, though perhaps that was going to happen anyway, since that is what girls did. The women's liberation movement was also a major influence but, as I approach the end of my academic life, I realise I owe ANU much more than I thought.

Rosemary Auchmuty is a professor of law at the University of Reading. Prior to moving into law she wrote widely in the areas of women's history and children's literature, including a school textbook, Australia's Daughters (1978), and two feminist studies of girls' school stories. As well as property law and gender and law, Rosemary's research interests include sexuality and feminist legal history. She is currently joint coordinator of a 100-strong collaboration called the Women's Legal Landmarks Project, a major historical collection in book and website formats, planned to celebrate the centenary in 2019 of women's admission to the legal profession in the UK and Ireland. 
This text is taken from ANU Historical Journal II: Number 1, published 2019 by ANU Press, The Australian National University, Canberra, Australia.

doi.org/10.22459/ANUHJII.2019.05 